\title{
Analisis Respon Pemakai Jasa Transportasi Taksi Konvensional Terhadap Keberadaan Taksi Online di Pontianak
}

\author{
Andry Lindi Lim \\ email: Vaynard_northgard@yahoo.com \\ Fakultas Ekonomi dan Bisnis \\ Universitas Widya Dharma Pontianak
}

\begin{abstract}
In its development, there is transportation that can be ordered and paid for online. A presence that is rife in Indonesia, especially in big cities since 2015. One of the transportation that can be ordered online is taxi. These applications include Go-Car and Grab Car. This study aims to determine the factors that influence the acceptance and use of online taxis in Pontianak according to the user, and the authors limit it to: Qualitative and Quantitative Analysis and Measures of Availability of Analysis of Public Facilities. Descriptive methods and data collection techniques are done by conducting interviews, documentary studies and questionnaires. The population is Conventional Taxi Service Users and Online Taxis in Pontianak. The sampling technique from the population used purposive sampling with 100 respondents. The results showed that Transportation Minister Decree Variable Number 26 Year 2017 Article 5 Regarding Transportation Services of People Using Conventional and Online Taxis has an overall average of 6.00 and 7.67, and Variable Size of Decision to Use Taxis has an overall average of 6.25 and 7.50.
\end{abstract}

Key words: Analysis of the taxi passengers

\begin{abstract}
Abstrak
Pada perkembangannya, terdapat transportasi yang dapat dipesan dan dibayar secara online. Kehadiran yang marak di Indonesia, khususnya kota-kota besar sejak tahun 2015. Salah satu transportasi yang dapat dipesan secara online adalah taxi. Aplikasi tersebut antara lain adalah Go-Car dan Grab Car. Penelitian ini bertujuan untuk mengetahui faktorfaktor yang mempengaruhi penerimaan dan penggunaan taxi online di Pontianak menurut pemakai dan penulis membatasinya pada: Analisis Kualitatif dan Kuantitatif dan Ukuran Ketersediaan Analisis Fasilitas Publik. Metode deskriptif dan teknik pengumpulan data dilakukan dengan melakukan wawancara, studi dokumenter dan kuesioner. Populasinya adalah para Pemakai Jasa Transportasi Taksi Konvensional sekaligus Taksi Online di Pontianak. Teknik pengambilan sampel dari populasi menggunakan purposive sampling dengan 100 responden. Hasil penelitian menunjukkan bahwa Variabel Keputusan Menteri Perhubungan Nomor 26 Tahun 2017 Pasal 5 Tentang Pelayanan Angkutan Orang dengan Menggunakan Taksi Konvensional dan Online memiliki rata-rata keseluruhan 6,00 dan 7,67, dan Ukuran Variabel Keputusan Memakai Taksi memiliki rata-rata keseluruhan 6,25 dan 7,50 .
\end{abstract}

Kata-kata kunci: Analisis penumpang taksi

\section{A. Pendahuluan}

Seiring dengan majunya teknologi dan ilmu pengetahuan, maka semakin mudah pula dalam memperoleh transportasi umum. Di saat perkembangan zaman 
yang sudah modern ini, banyak transportasi daring yang dapat digunakan dan transaksinya dilakukan secara online maupun tunai. Kehadiran yang marak di Indonesia, khususnya kota-kota besar sejak tahun 2015. Salah satu transportasi yang dapat dipesan secara online adalah taxi. Aplikasi tersebut antara lain adalah Go-Car dan Grab Car. Penelitian ini bertujuan untuk mengetahui faktor-faktor yang mempengaruhi penerimaan dan penggunaan taxi online di Pontianak menurut customer. Hal ini yang terjadi dan marak di Indonesia, khususnya kota-kota besar sejak tahun 2015 yaitu fenomena angkutan umum online, salah satunya adalah taxi online. Keduanya menawarkan layanan pengantaran dengan kendaraan jenis Multi Purpose Vehicle (MPV), Family Car dan Sedan. Masing-masing menerapkan sistem tarif yang berbeda. Go-Car menggunakan sistem tarif dasar sesuai dengan hitungan aplikasi. Sedangkan Grab Car menawarkan tarif dasar sesuai dengan yang tertera dalam aplikasi.

Kedua aplikasi juga menawarkan sistem pembayaran yang berbeda-beda. Go-Car dari Gojek menawarkan pilihan pembayaran secara tunai atau secara non tunai dengan Go Pay. Gojek menyediakan Go-Pay yang berfungsi sebagai dompet elektronik kepada penggunanya. Saldo dompet Go Pay dapat berasal dari pengiriman dana transfer maupun pengisian yang dilakukan oleh driver Gojek. Dalam pembayaran tunai ataupun non tunai ditawarkan aplikasi Grab Car ataupun Grab Pay. Layanan Grab Pay serupa dengan Go Pay, namun sumber dana bisa berasal dari kartu kredit dan kartu debit aneka bank, serta tidak menetapkan biaya atas pembatalan pemesanan.

Taxi online tersebut pun kini juga sudah mulai beroperasi di wilayah Pontianak, namun fenomena taxi online baru dikenal dan marak di Pontianak pada awal tahun 2017 sejak masuknya beberapa perusahaan penyedia layanan transportasi online seperti Gojek dan Grab. Lalu sebagai teknologi yang masih baru, perlu dilakukan peninjauan dari penggunaan aplikasi taxi online dalam berbagai aspek, seperti: ekspektasi kinerja, ekspektasi usaha, pengaruh sosial, dan kondisi pendukung yang semuanya itu berpengaruh terhadap niat dan perilaku penggunaan teknologi.

Sokongan bagi taksi online diberikan Sutarmiji-Calon Gubernur Kalbar, seperti Gojek juga yang lain untuk beroperasi dengan legal di Kota Pontianak dan sekitarnya, secara garis besar didukung kehadiran Gojek maupun taksi online di Kota Pontianak. Gimana tidak mendukung, anak-anak saya saja sering pesan makanan lewat Gofood," kata Sutarmidji di Pontianak, Minggu. la menjelaskan, dukungan tersebut, diakuinya telah dilakukan dengan meminta kepada para pengurus taksi online untuk membenahi legalitas serta urusan administrasi yang telah diatur dan ditetapkan tersebut. Keluhan masyarakat bisa terakomodir dengan pembukaan kantor yang bisa menampung masyarakat yang hendak komplain atau ketidakpuasan bisa bersifat langsung. Sementara itu, Izan, salah satu driver Gojek mengaku akan mendukung pasangan Calon Gubernur dan Wakil Gubernur Sutarmidji-Ria Norsan jika pasangan tersebut mendukung sepenuhnya taksi online 
yang kini menjadi salah satu tempat mencari rejeki bagi ia dan ribuan driver lainnya itu.

"Sebelumnya saya mendengar Pak Midji tidak dukung taksi online, tapi kalau sudah diklarifikasi mendukung, jelas saya dukung beliau menjadi Gubernur Kalbar periode mendatang," ujarnya. la menambahkan, dirinya akan menginformasikan kepada ribuan rekan taksi online yang ada se-Kalbar, pasangan nomor urut tiga ternyata mendukung sepenuhnya taksi online beroperasi di Pontianak. Pontianak (Antara News)-Minggu, 25 Februari 2018. Penelitian ini bertujuan untuk mengetahui faktor-faktor yang mempengaruhi penerimaan dan penggunaan taxi online (Go-Car dan Grab Car) di Pontianak menurut pemakai.

Aturan baru taksi online telah resmi berlaku mulai hari Selasa (18/6/2019), sesuai dengan Peraturan Menteri Perhubungan (Permenhub) Nomor 118 Tahun 2018. Artinya, kini keberlangsungan operasi taksi online yang tengah dikuasai oleh dua perusahaan aplikasi (aplikator) raksasa memiliki koridor yang harus dipatuhi. Dengan berlakunya Permenhub No. 118 tahun 2019, ketidaksamaan tarif taksi konvensional dan taksi online terjadi peluang perbedaan dan menjadi lebih tidak lebar. Apalagi bila nanti di setiap daerah tarif batas bawah yang ditetapkan oleh pemerintah setara dengan tarif batas bawah taksi konvensional. Namun tetap saja taksi konvensional masih berada pada posisi yang lebih tidak diuntungkan. Pasalnya saat ini TBA dan TBB yang diatur hanya tarif per kilometer. Taksi konvensional misalnya menyebut ada istilah tarif buka pintu. Karena pada kenyataannya, taksi online memiliki bisnis model yang lebih luas dibanding taksi konvensional. Aplikator memiliki segudang jalur pendapatan. Contohnya pada dua aplikator taksi online saat ini ada yang namanya jasa pemesanan makanan, yang tentunya mengambil marjin dari setiap pemesanan (tidak termasuk biaya pengantaran). Dengan nilai pendapatan yang besar tersebut, aplikator jadi punya ruang yang lebih luas untuk mengatur biaya perjalanan orang. Aplikator bisa saja tidak mengambil untung dari operasional pengantaran orang, karena masih bisa mendapatkan keuntungan dari transaksi makanan. Sementara taksi konvensional tidak dapat menerapkan hal itu, karena pengantaran orang merupakan kanal bisnis utamanya. Taksi konvensional akan selalu mengusahakan keuntungan dari operasional pengantaran orang, yang mau tidak mau harus mengambil marjin dari setiap perjalanan. Konsekuensi logis untuk kasus yang berkembang terakhir, tarif taksi online akan lebih murah dibandingkan taksi konvensional. Dari segi tarif, sulit untuk mencapai kesetaraan. Di tengah masyarakat kelas menengah Indonesia yang sangat sensitif terhadap harga sebuah produk, taksi konvensional mau tak mau harus mencari keunggulan lain yang bisa meningkatkan daya saing. (CNBC Indonesia. Jakarta. 19 June 2019).

Faktor ketertarikan memakai transportasi dikarenakan, antara lain:

1. Kepercayaan terhadap jasa,

2. Persepsi kemudahan yang akan diterima,

3. Persepsi risiko,

4. Harga jasa tersebut. 
Variasi perhitungan dalam perjalanan dilakukan pihak masyarakat, baik masalah efisiensi, atau biaya yang bisa didapat. Salah satu ialah harga. Penerapan tarif taksi berbasis online ini tidak sama, Grab Car menawarkan tarif datar sesuai aplikasi, sedangkan Go-car sesuai kilometer yang ditempuh. Jika dibanding, tarif taksi konvensional tersebut memiliki tarif yang lebih mahal dibandingkan taksi berbasis online. Penggunaan tarif taksi berbasis online yang seterang itu juga menambah nilai ketertarikan bagi pihak masyarakat guna menentukan jasa.

Saat tertentu yaitu pada jam sibuk dan saat permintaan tinggi, serta saat cuaca tidak bersahabat, dan pengaturan tarif batas atas dilakukan untuk melindungi konsumen agar tidak ada kenaikan tarif taksi berbasis online pada waktu tertentu. Pengaturan tarif batas bawah diatur biar terjadi kompetisi atau kesetaraan dalam usaha transportasi. Layanan taksi berbasis online ini juga dimungkinkan memberikan diskon. Dengan berlakukanya tarif batas atas dan bawah bagi taksi berbasis online, akan memberikan dampak. Pertama, masyarakat akan mengkalkulasikan kondisi yang untuk memakai kendaraan personal atau taksi berbasis online dari sudut pandang biaya dan efisiensi. Kedua, penyesuaian tarif taksi berbasis online dengan penentuan batas tertinggi dan terendah juga menimbulkan positif, mencegah kekerasan yang terjadi selama ini agar penggunaan teknologi digital bisa dirasakan masyarakat secara maksimal dan tidak negatif bagi taksi konvensional yang telah lebih dulu beroperasi. Kementerian Perhubungan juga mendorong taksi konvensional untuk terus berbenah diri, dan selali meningkatkan pelayanan pada masyarakat. (Majalah Info Singkat Ekonomi dan Kebijakan Publik. Kajian Singkat Terhadap Isu Aktual dan Strategis. Vol. IX, No. 06/II/Puslit/Maret/2017).

Total penduduk Kota Pontianak Semester I Tahun 2019:

Tabel 1

Jumlah Penduduk Kota Pontianak Semester I Tahun 2019

\begin{tabular}{lcrr}
\multicolumn{1}{c}{ Kecamatan } & \multicolumn{3}{c}{ JUMLAH PENDUDUK } \\
\hline PONTIANAK BARAT & LAKI-LAKI & PEREMPUAN & \multicolumn{1}{c}{ TOTAL } \\
PONTIANAK KOTA & 75.344 & 74.806 & $\mathbf{1 5 0 . 1 5 0}$ \\
PONTIANAK SELATAN & 62.924 & 63.676 & $\mathbf{1 2 6 . 6 0 0}$ \\
PONTIANAK TENGGARA & 46.172 & 46.842 & 93.014 \\
PONTIANAK TIMUR & 24.443 & $\mathbf{2 4 . 5 8 3}$ & 49.026 \\
PONTIANAK UTARA & 52.383 & 51.896 & $\mathbf{1 0 4 . 2 7 9}$ \\
\hline JUMLAH & 72.906 & $\mathbf{7 1 . 0 7 8}$ & $\mathbf{1 4 3 . 9 8 4}$ \\
\hline
\end{tabular}

\section{B. Kajian Teori}

Pemindahan barang dan manusia dari tempat asal ke tempat tujuan merupakan arti transportasi. Dengan begitu maka terdapat tiga hal yaitu adanya muatan yang bisa diangkut, tersedianya kendaraan sebagai alat angkut dan terdapatnya jalan yang dapat dilalui. (Nasution, 1996). Transportasi merupakan 
pergerakan tingkah laku orang dalam ruang baik dalam membawa dirinya sendiri maupun membawa barang-barang. (Rifusa, 2010). Selain itu, menurut mengungkapkan bahwa prasarana transportasi mempunyai dua peran utama, yaitu: (1) sebagai alat bantu untuk mengarahkan pembangunan di daerah perkotaan dan (2) sebagai prasarana bagi pergerakan manusia dengan/atau barang yang terjadi karena aktivitas di daerah perkotaan dimaksud. Transportasi adalah perpindahan orang atau barang dari satu tempat ke tempat yang lainnya atau dari tempat asal ke tempat tujuan dengan menggunakan wahana digerakan manusia, hewan atau mesin. (Sani, 2012).

Proses pemindahan dari gerakan tempat asal, di mana kegiatan pengangkutan dimulai dan ke tempat tujuan di mana kegiatan diakhiri. Karena memindahkan barang dan orang tersebut tadi maka fungsi transportasi adalah salah satu sektor yang bias memberikan tunjangan kegiatan pemberi jasa dan kegiatan ekonomi bagi perkembangan ekonomi. (Rifusa, 2010). Transportasi diartikan sebagai usaha memindahkan, menggerakkan, mengangkut, atau mengalihkan suatu objek dari suatu tempat ke tempat lain, sehingga di lokasi lain tersebut objek menjadi lebih bermanfaat atau dapat berguna untuk suatu tujuan-tujuan tertentu (Miro, 2004).

Ditinjau dari pemenuhan dari kebutuhan mobilitasnya, masyarakat pengguna transportasi umum dapat dibagi menjadi dua bagian utama yaitu:

a. Kelompok choice, adalah kelompok orang yang secara finansial mempunyai pilihan dalam memenuhi mobilitas perjalanannya.

b. Kelompok captive, merupakan kelompok orang yang secara finansial ataupun kemampuan, tidak mempunyai banyak pilihan dalam memenuhi mobilitas perjalanannya dan sangat tergantung pada kendaraan umum yang ada. (Salim, 2013).

Salah satu tatanan yang mengalami perubahan gradual adalah sektor ekonomi di mana revolusi teknologi telah mengubah cara masyarakat dalam memproduksi, distribusi dan mengkonsumsi segala sesuatu. Saat ini revolusi telah memasuki fase ketiga di mana revolusi yang pertama merupakan revolusi industri yang ditandai dengan penemuan mesin (uap) yang pada akhirnya sedikit banyak telah menggantikan peran manusia dan ternak (hewan) dalam proses produksi. Fase revolusi kedua ditandai dengan penerapan jalur perakitan untuk meningkatkan efektifitas dan efisiensi proses produksi (fordisme) di mana revolusi ini memungkinkan produksi dilakukan secara massal. Produksi dengan model fordisme menekan harga jual dan memperbesar pasar secara cepat. Fase revolusi ketiga diawali dengan semakin berkembangnya teknologi terutama teknologi digital di mana proses ini membuat proses produksi, distribusi dan konsumsi menjadi jauh lebih efisien. Revolusi teknologi juga kemudian menjadi awal dari perubahan pola perilaku dan perubahan struktur sosial di masyarakat. Revolusi teknologi mendorong perubahan dan perkembangan industri yang berbasis digital. Hal ini juga didorong dengan semakin tergantungnya masyarakat atas informasi yang cepat sehingga menyebabkan teknologi digital tumbuh dan berkembang dengan pesat. Industri digital tumbuh dengan memunculkan perubahan dan kemudahan sebagai jargon 
untuk menarik minat masyarakat. Terlebih masyarakat yang saat ini merupakan generasi $Y$ dan $Z$ yang memang tumbuh dan berkembang seiring dengan kelahiran dan perkembangan teknologi. Industri berbasis digital tumbuh dan berkembang dengan cepat dengan dukungan layanan internet, kemudahan perangkat (gadget/telepon pintar) hingga kebutuhan masyarakat akan kemudahan yang pada akhirnya menjadi pemicu kelahiran aplikasi-aplikasi digital berbasis layanan data yang memudahkan manusia dalam berinteraksi maupun pendukung aktivitas seharihari. Era booming media sosial (facebook, twitter, instagram, dan lain-lain) saat ini diikuti dengan merebaknya berbagai aplikasi-aplikasi yang memudahkan manusia dalam melakukan apa yang mereka inginkan. Lapak-lapak online mulai banyak bermunculan dan mengubah cara masyarakat dalam berbelanja. Pasar dalam konsep tradisonal telah berganti rupa dengan penyediaan barang secara maya melalui kanal-kanal online yang menyediakan kemudahan dalam berbelanja, bertransaksi dengan sekali klik memberikan adiksi bagi masyarakat untuk selalu menggunakannya. Kemudahan itu kemudian didukung dengan aplikasi yang bisa diunduh di telepon sehingga di manapun dan kapanpun masyarakat dapat bertransaksi secara mudah dan cepat tanpa perlu menatap layar komputer di rumah. Kemudahan-kemudahan tersebut tidak hanya didukung oleh pengembangan teknologi tetapi juga didorong oleh keinginan masyarakat (konsumen) akan kemudahan. Layanan aplikasi untuk memudahkan konsumen pada akhirnya kemudian berkembang dengan memberikan kemudahan dalam beberapa kegiatan penunjang aktivitas masyarakat. Salah satu yang kemudian berkembang adalah layanan ride sharing (berbagi kendaraan) yang pada awalnya bertujuan untuk memudahkan masyarakat memperoleh kendaraan sebagai alat transportasi yang aman, cepat dan pasti. Gagasan ride sharing ini dimulai dengan munculnya uber taxi yang disusul dengan beberapa aplikasi lainnya. Pada awalnya layanan ride sharing ini banyak ditentang terutama oleh penyedia transportasi yang telah mapan. Bahkan hingga sekarang konflik antara penyedia tranportasi tradisional versus berbasis aplikasi masih tampak nyata dan tidak menunjukkan tanda-tanda adanya konsensus.

\section{Moda Transportasi}

Jenis Pelayanan Transportasi yang diurai dalam penelitian ini membahas angkutan konvensional berupa taksi konvensional (Taksi Bandara) dan moda transportasi yang baru yaitu moda transportasi online (Go-Car dan Grab Car).

\section{Taksi Konvensional}

Taksi adalah pelayanan transportasi yang telah disediakan penyedia jasa dan dapat digunakan dengan orang lain dengan menyetujui suatu kondisi atau perjanjian yang menyesuaikan dengan keinginan dari pengguna. Taksi merupakan moda angkutan umum yang memakai mobil untuk membawa penumpang dalam kapasitas kecil. Tarif taksi dihitung melaui dua cara, menggunakan argometer yang dihitung dengan otomatis sesuai jumlah jarak yang ditempuh dan cara lain berdasarkan 
kesepakatan antara penumpang dan pengemudi taksi. Taksi sebagai moda transportasi memiliki beberapa kelebihan dan kekurangan. Kelebihan yang dimiliki taksi di antaranya:

1. Pemakai jasa dapat merubah jadwal serta jalur perjalanan yang dinamis dari taksi yang bersifat fleksibel.

2. Kemudahan dan keenakan yang disiapkan taksi lebih baik dibandingkan dengan moda transportasi lain.

3. Taksi merupakan moda transportasi resmi yang beroperasi di Indonesia.

4. Tepat waktu.

5. Keamanan dan privasi terjamin.

Sedangkan kekurangan yang dimiliki taksi, di antaranya:

1. Taksi hanya dapat membawa kurang lebih empat orang penumpang dan penumpang tersebut biasanya berada di suatu kelompok.

2. Biaya taksi lebih mahal dibandingkan dengan biaya lainnya.

\section{Transportasi Online}

Kendaraan pribadi roda empat yang dioperasionalkan sebagai moda transportasi online secara umum yang pemesanannya dilakukan dengan aplikasi secara online dan bertujuan untuk mempermudah seseorang yang ingin pergi ke lokasi lain. Transportasi online sebagai salah satu moda transportasi juga memiliki beberapa kelebihan dan kekurangan. Kelebihan transportasi online seperti:

1. Pemesanan yang lebih mudah dilakukan karena melalui aplikasi secara online.

2. Tarif yang lebih murah dan terdapat transparansi, sehingga pengguna dapat mengetahui harga tarif sebelum melakukan pemesanan.

3. Waktu perjalanan yang lebih efisien dan efektif karena tidak perlu menunggu terlalu lama, aplikasi akan menentukan driver yang terdekat dengan lokasi penjemputan.

4. Pengguna dapat menentukan lokasi penjemputan di mana saja dan dapat langsung sampai ke lokasi tujuan tanpa berganti moda transportasi lain.

Selain memiliki banyak kelebihan, transportasi online juga memiliki kekurangan seperti:

1. Moda transportasi di Indonesia belum memiliki kekuatan aspek hukum transportasi online sehingga belum diakui secara resmi.

2. Tidak terdapat uji KIR pada transportasi online.

3. Permasalahan jaringan yang sering terjadi sehingga pada saat tertentu pemesanan tidak bisa dilakukan.

4. Peningkatan volume lalu lintas kendaraan karena banyaknya kendaraan mobil maupun motor pribadi yang beroperasi sebagai transportasi online. (Laporan Penelitian Dilema Sosial Ojek Online Gojek(1).pdf, 2019)

\section{Metode Penelitian}

Bentuk penelitian adalah dengan metode deskriptif. "Penelitian deskriptif merupakan penelitian yang berpola menggambarkan apa yang ada di lapangan dan 
mengupayakan penggambaran data, terlepas apakah data itu kualitatif ataupun kuantitatif". (Sudjarwo, 2001). "Wawancara adalah cara pengumpulan data dengan langsung mengadakan suatu tanya jawab kepada objek yang diteliti atau kepada perantara yang mengetahui persoalan dari objek yang sedang diteliti". (Hasan, 2002).

Studi Dokumenter dilakukan, populasi adalah para Pemakai Jasa Transportasi Taksi Konvensional Terhadap Keberadaan Taksi Online di Pontianak. Teknik pengambilan sampel dari populasi menggunakan purposive sampling dengan responden 100 orang. Teknik analisis yang digunakan adalah teknik analisis kualitatif. "Penelitian kualitatif adalah suatu penelitian yang tidak hanya menemukan dan menunjukkan sifat-sifat dari kategori-kategori saja, melainkan dapat menjelaskan bagaimana dan mengapa kategori-kategori tersebut saling mempengaruhi”. (Rangkuti, 1997).

Variabel penelitian yang menjadi batasan pembahasan dalam penelitian ini adalah:

1. Keputusan Menteri Perhubungan Nomor 26 Tahun 2017 Pasal 5 Tentang Pelayanan Angkutan Orang dengan Menggunakan Taksi:

a. Wilayah operasi pelayanan berada di dalam kawasan perkotaan,

b. Tidak berjadwal,

c. Pelayanan dari pintu ke pintu,

d. Tujuan perjalanan ditentukan oleh pengguna jasa,

e. Tarif angkutan berdasarkan argometer atau tertera pada aplikasi berbasis teknologi informasi,

f. Besaran tarif berdasarkan tarif batas atas dan batas bawah yang ditetapkan oleh pejabat yang berwenang sesuai ketentuan peraturan perundangundangan,

g. Wajib memenuhi standar pelayanan minimal yang ditetapkan,

h. Pembayaran pada pelayanan angkutan taksi yang dilakukan berdasarkan argometer dilengkapi dengan alat bukti pembayaran yang tercetak, dan

i. Pemesanan dapat dilakukan melalui aplikasi berbasis teknologi informasi

2. Keputusan Memakai Taksi, mencakup:

a. Frekuensi Memakai,

b. Perasaan Puas atas Pelayanan,

c. Perasaan Puas atas Fasilitas, dan

d. Perasaan Untuk Tidak Memilih Taksi yang Lain (Loyalitas).

\section{Hasil Analisis Data Penelitian dan Pembahasan}

1. Analisis Respon Pemakai Jasa Transportasi Taksi Konvensional di Pontianak 
Tabel 2

Rekapitulasi Hasil Tanggapan Responden

Pemakai Jasa Transportasi Taksi Konvensional di Pontianak

\begin{tabular}{|c|c|c|c|}
\hline No & Pernyataan & $\begin{array}{c}\text { Nilai } \\
\text { Rata-rata }\end{array}$ & Kriteria \\
\hline A. & $\begin{array}{l}\text { Keputusan Menteri Perhubungan } \\
\text { Tahun } 2017 \text { Pasal } 5 \text { Tentang } 26 \\
\text { Pelayanan } \\
\text { Angkutan Orang dengan Menggunakan Taksi }\end{array}$ & & \\
\hline 1 & $\begin{array}{l}\text { Wilayah operasi pelayanan berada di dalam } \\
\text { kawasan perkotaan }\end{array}$ & 6 & Banyak \\
\hline 2 & Tidak berjadwal & 6 & Banyak \\
\hline 3 & Pelayanan dari pintu ke pintu & 6 & Banyak \\
\hline 4 & Tujuan perjalanan ditentukan oleh pengguna jasa & 6 & Banyak \\
\hline 5 & $\begin{array}{l}\text { Tarif angkutan berdasarkan argometer atau tertera } \\
\text { pada aplikasi berbasis teknologi informasi }\end{array}$ & 6 & Banyak \\
\hline 6 & $\begin{array}{l}\text { Besaran tarif berdasarkan tarif batas atas dan batas } \\
\text { bawah yang ditetapkan oleh pejabat yang } \\
\text { berwenang sesuai ketentuan peraturan } \\
\text { perundangundangan }\end{array}$ & 6 & Banyak \\
\hline 7 & $\begin{array}{l}\text { Wajib memenuhi standar pelayanan minimal yang } \\
\text { ditetapkan }\end{array}$ & 6 & Banyak \\
\hline 8 & $\begin{array}{l}\text { Pembayaran pada pelayanan angkutan taksi yang } \\
\text { dilakukan berdasarkan argometer dilengkapi dengan } \\
\text { alat bukti pembayaran yang tercetak }\end{array}$ & 6 & Banyak \\
\hline \multirow[t]{2}{*}{9} & $\begin{array}{l}\text { Pemesanan dapat dilakukan melalui aplikasi } \\
\text { berbasis teknologi informasi }\end{array}$ & 6 & Banyak \\
\hline & Rata-rata Keseluruhan & 6,00 & \\
\hline B. & Keputusan Memakai Taksi & & \\
\hline 1 & Frekuensi Memakai & 6 & Banyak \\
\hline 2 & Perasaan Puas atas Pelayanan & 7 & Banyak \\
\hline 3 & Perasaan Puas atas Fasilitas & 6 & Banyak \\
\hline \multirow[t]{2}{*}{4} & $\begin{array}{l}\text { Perasaan Untuk Tidak Memilih Taksi yang Lain } \\
\text { (Loyalitas) }\end{array}$ & 6 & Banyak \\
\hline & Rata-rata Keseluruhan & 6,25 & \\
\hline
\end{tabular}

Berikut diuraikan analisis tanggapan responden terhadap masing-masing variabel:

a. Keputusan Menteri Perhubungan Nomor 26 Tahun 2017 Pasal 5 Tentang Pelayanan Angkutan Orang dengan Menggunakan Taksi.

Nilai rata-rata keseluruhan sebesar 6,00 yang berarti sekitar minimal 60,00 persen responden memilih "banyak". 
b. Keputusan Memakai Taksi.

Nilai rata-rata keseluruhan sebesar 6,25 yang berarti sekitar minimal 62,50 persen responden memilih "banyak".

2. Analisis Respon Pemakai Jasa Transportasi Taksi Online di Pontianak

Tabel 3

Rekapitulasi Hasil Tanggapan Responden Pemakai Jasa Transportasi Taksi Online di Pontianak

\begin{tabular}{|c|c|c|c|}
\hline No & Pernyataan & $\begin{array}{c}\text { Nilai } \\
\text { Rata-rata }\end{array}$ & Kriteria \\
\hline A. & $\begin{array}{l}\text { Keputusan Menteri Perhubungan Nomor } 26 \\
\text { Tahun } 2017 \text { Pasal } 5 \text { Tentang Pelayanan } \\
\text { Angkutan Orang dengan Menggunakan } \\
\text { Taksi }\end{array}$ & & \\
\hline 1 & $\begin{array}{l}\text { Wilayah operasi pelayanan berada di dalam } \\
\text { kawasan perkotaan }\end{array}$ & 7 & Banyak \\
\hline 2 & Tidak berjadwal & 8 & $\begin{array}{l}\text { Banyak } \\
\text { Sekali }\end{array}$ \\
\hline 3 & Pelayanan dari pintu ke pintu & 8 & $\begin{array}{l}\text { Banyak } \\
\text { Sekali }\end{array}$ \\
\hline 4 & $\begin{array}{l}\text { Tujuan perjalanan ditentukan oleh pengguna } \\
\text { jasa }\end{array}$ & 7 & Banyak \\
\hline 5 & $\begin{array}{l}\text { Tarif angkutan berdasarkan argometer atau } \\
\text { tertera pada aplikasi berbasis teknologi } \\
\text { informasi }\end{array}$ & 8 & $\begin{array}{l}\text { Banyak } \\
\text { Sekali }\end{array}$ \\
\hline 6 & $\begin{array}{l}\text { Besaran tarif berdasarkan tarif batas atas dan } \\
\text { batas bawah yang ditetapkan oleh pejabat } \\
\text { yang berwenang sesuai ketentuan peraturan } \\
\text { perundangundangan }\end{array}$ & 8 & $\begin{array}{l}\text { Banyak } \\
\text { Sekali }\end{array}$ \\
\hline 7 & $\begin{array}{l}\text { Wajib memenuhi standar pelayanan minimal } \\
\text { yang ditetapkan }\end{array}$ & 8 & $\begin{array}{l}\text { Banyak } \\
\text { Sekali }\end{array}$ \\
\hline 8 & $\begin{array}{l}\text { Pembayaran pada pelayanan angkutan taksi } \\
\text { yang dilakukan berdasarkan argometer } \\
\text { dilengkapi dengan alat bukti pembayaran yang } \\
\text { tercetak }\end{array}$ & 7 & Banyak \\
\hline 9 & $\begin{array}{l}\text { Pemesanan dapat dilakukan melalui aplikasi } \\
\text { berbasis teknologi informasi }\end{array}$ & 8 & $\begin{array}{l}\text { Banyak } \\
\text { Sekali }\end{array}$ \\
\hline & Rata-rata Keseluruhan & 7,67 & \\
\hline B. & Keputusan Memakai Taksi & & \\
\hline 1 & Frekuensi Memakai & 7 & Banyak \\
\hline
\end{tabular}




\begin{tabular}{|c|c|c|c|}
\hline 2 & Perasaan Puas atas Pelayanan & 8 & $\begin{array}{l}\text { Banyak } \\
\text { Sekali }\end{array}$ \\
\hline 3 & Perasaan Puas atas Fasilitas & 7 & Banyak \\
\hline 4 & $\begin{array}{l}\text { Perasaan Untuk Tidak Memilih Taksi yang Lain } \\
\text { (Loyalitas) }\end{array}$ & 8 & Banyak Sekali \\
\hline & Rata-rata Keseluruhan & 7,50 & \\
\hline
\end{tabular}

Sumber: Data olahan, 2020

Berikut diuraikan analisis tanggapan responden terhadap masing-masing variabel:

a. Keputusan Menteri Perhubungan Nomor 26 Tahun 2017 Pasal 5 Tentang Pelayanan Angkutan Orang dengan Menggunakan Taksi

Nilai rata-rata keseluruhan sebesar 7,67 yang berarti sekitar minimal 76,70 persen responden memilih "banyak".

b. Keputusan Memakai Taksi.

Nilai rata-rata keseluruhan sebesar 7,50 yang berarti sekitar minimal 75,00 persen responden memilih "banyak".

3. Analisis Urutan Tingkat Nilai Rata-rata Keseluruhan Tertinggi Sampai Terendah

Tabel 4

Urutan Tingkat Nilai Rata-Rata Keseluruhan

Tertinggi Sampai Terendah

Pemakai Jasa Transportasi Taksi Konvensional di Pontianak

\begin{tabular}{|c|l|c|}
\hline $\begin{array}{c}\text { No } \\
\cdot\end{array}$ & \multicolumn{1}{|c|}{ Variabel } & $\begin{array}{c}\text { Nilai Rata- rata } \\
\text { Keseluruhan }\end{array}$ \\
\hline 1 & $\begin{array}{l}\text { Keputusan Menteri Perhubungan Nomor 26 Tahun 2017 } \\
\text { Pasal 5 Tentang Pelayanan Angkutan Orang dengan } \\
\text { Menggunakan Taksi }\end{array}$ & 6,00 \\
\hline 2 & Keputusan Memakai Taksi & 6,25 \\
\hline
\end{tabular}

TABEL 5

Urutan Tingkat Nilai Rata-Rata Keseluruhan

Tertinggi Sampai Terendah

Pemakai Jasa Transportasi Taksi Online di Pontianak

\begin{tabular}{|c|c|c|}
\hline $\begin{array}{c}\text { No } \\
\cdot\end{array}$ & Variabel & $\begin{array}{c}\text { Nilai Rata-rata } \\
\text { Keseluruhan }\end{array}$ \\
\hline 1 & $\begin{array}{l}\text { Keputusan Menteri Perhubungan Nomor 26 Tahun 2017 } \\
\text { Pasal 5 Tentang Pelayanan Angkutan Orang dengan }\end{array}$ & 7,67 \\
\hline
\end{tabular}


Vol. 5 No.1`Maret 2020

\begin{tabular}{|c|l|c|}
\hline & Menggunakan Taksi & \\
\hline 2 & Keputusan Memakai Taksi & 7,50 \\
\hline
\end{tabular}

Sumber: Data olahan, 2020

4. Bukti SPSS

a. Uji Normalitas

Taksi Konvensional

\begin{tabular}{|c|c|c|}
\hline \multicolumn{3}{|c|}{ One-Sample Kolmogorov-Smirnov Test } \\
\hline & & $\begin{array}{l}\text { Unstandardiz } \\
\text { ed Residual }\end{array}$ \\
\hline $\mathrm{N}$ & & 114 \\
\hline \multirow[t]{2}{*}{ Normal Parameters ${ }^{a, b}$} & Mean &, 0000000 \\
\hline & Std. Deviation & 2,11357305 \\
\hline \multirow[t]{3}{*}{ Most Extreme Differences } & Absolute &, 037 \\
\hline & Positive &, 032 \\
\hline & Negative &,- 037 \\
\hline Test Statistic & &, 037 \\
\hline Asymp. Sig. (2-tailed) & & $200^{c, d}$ \\
\hline
\end{tabular}

a. Test distribution is Normal.

b. Calculated from data.

c. Lilliefors Significance Correction.

$$
\text { Histogram }
$$

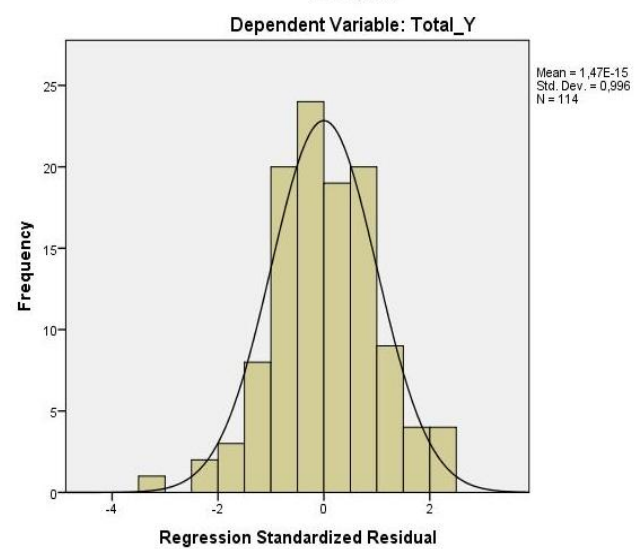

Normal P-P Plot of Regression Standardized Residual

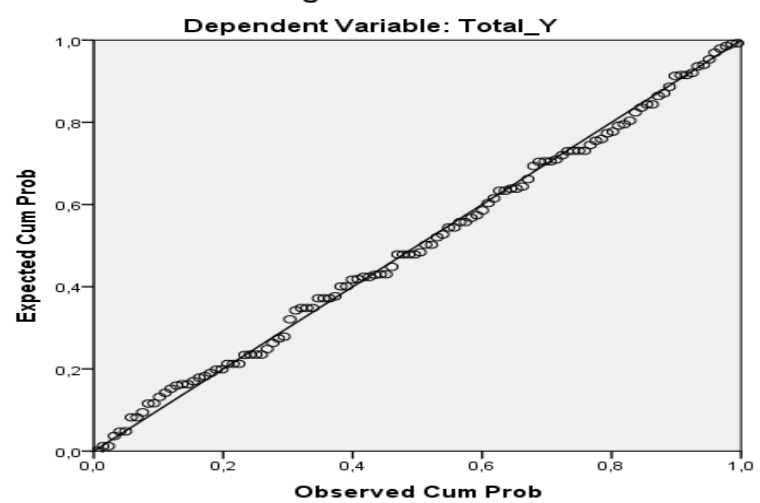

b. Uji Multikolonieritas

Taksi Konvensional

Coefficients $^{a}$

\begin{tabular}{|lr|r|r|}
\hline \multirow{2}{*}{ Model } & \multicolumn{2}{|c|}{ Collinearity Statistics } \\
\cline { 2 - 4 } & Tolerance & \multicolumn{1}{c|}{ VIF } \\
\hline 1 & Total_k & 1,000 & 1,000 \\
\hline
\end{tabular}

a. Dependent Variable: Total_Y
Taksi Online

One-Sample Kolmogorov-Smirnov Test
\begin{tabular}{|ll|r|}
\hline \multicolumn{1}{|c|}{} & $\begin{array}{r}\text { Unstandardiz } \\
\text { ed Residual }\end{array}$ \\
\hline $\mathrm{N}$ & & 100 \\
Normal Parameters & Meb &, 0000000 \\
& Std. Deviation & 2,15913396 \\
Most Extreme Differences & Absolute &, 079 \\
& Positive &, 079 \\
& Negative &,- 069 \\
Test Statistic & &, 079 \\
Asymp. Sig. (2-tailed) & &, $123^{\text {c }}$ \\
\hline
\end{tabular}

a. Test distribution is Normal.

b. Calculated from data.

c. I illipfore Sirnificance Corroction
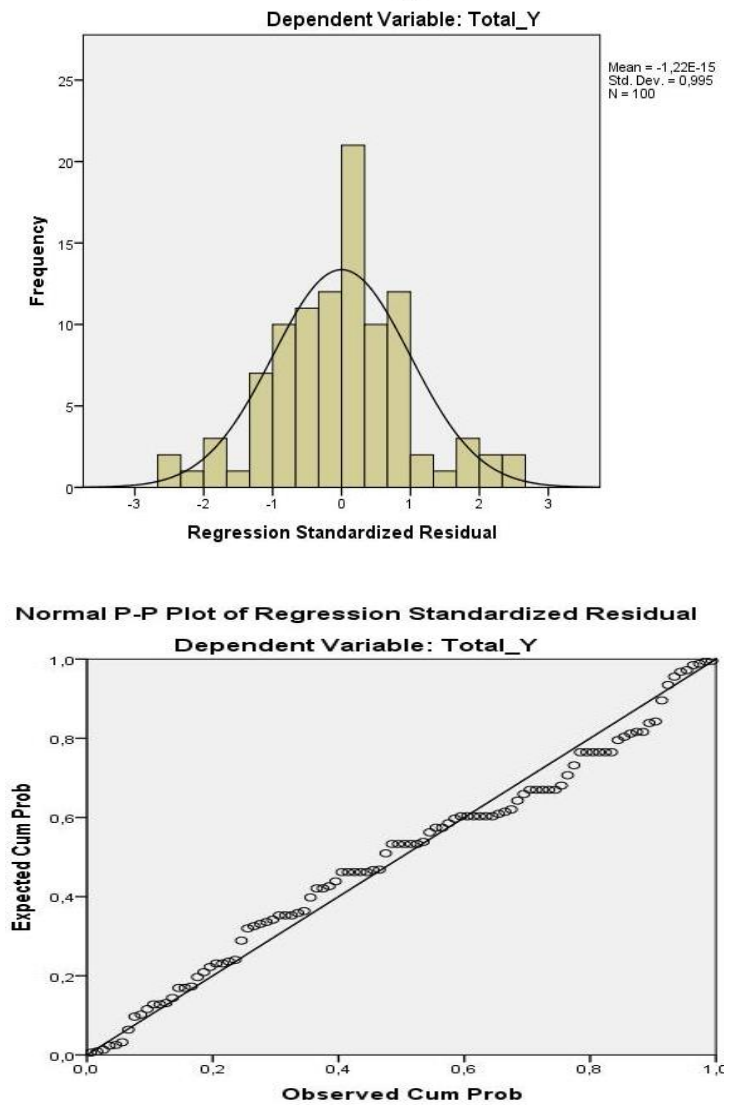

Taksi Online

Coefficients $^{a}$

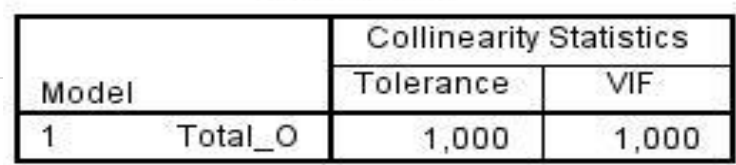

a. Dependent Variable: Total_Y 
c. Uji Heteroskedastisitas

\section{Taksi Konvensional}

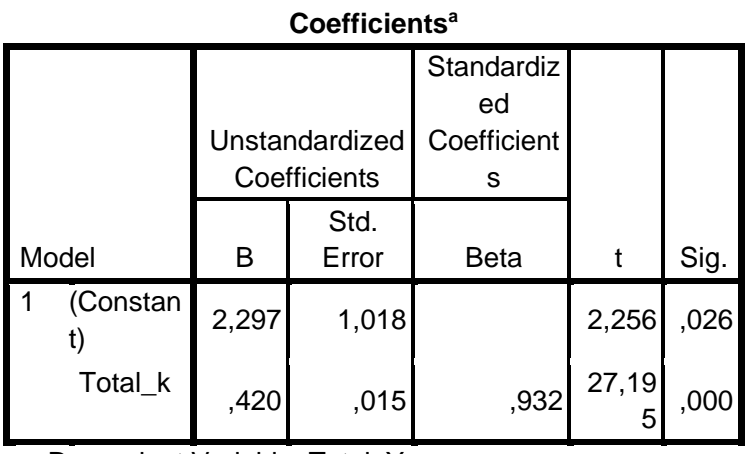

a. Dependent Variable: Total_Y

\section{d. Uji Autokorelasi}

Taksi Konvensional

\section{Model Summary}

\begin{tabular}{|l|c|r|r|r|r|}
\hline Model & $\mathrm{R}$ & $\begin{array}{c}\mathrm{R} \\
\text { Squar } \\
\mathrm{e}\end{array}$ & $\begin{array}{c}\text { Adjuste } \\
\mathrm{d} \mathrm{R} \\
\text { Square }\end{array}$ & $\begin{array}{c}\text { Std. Error } \\
\text { of the } \\
\text { Estimate }\end{array}$ & $\begin{array}{c}\text { Durbin } \\
\text { Watson }\end{array}$ \\
\hline 1 &, $932^{\mathrm{a}}$ &, 868 &, 867 & 2,123 & 2,003 \\
\hline
\end{tabular}

a. Predictors: (Constant), Total $k$

b. Dependent Variable: Total_Y

\section{Taksi Online}

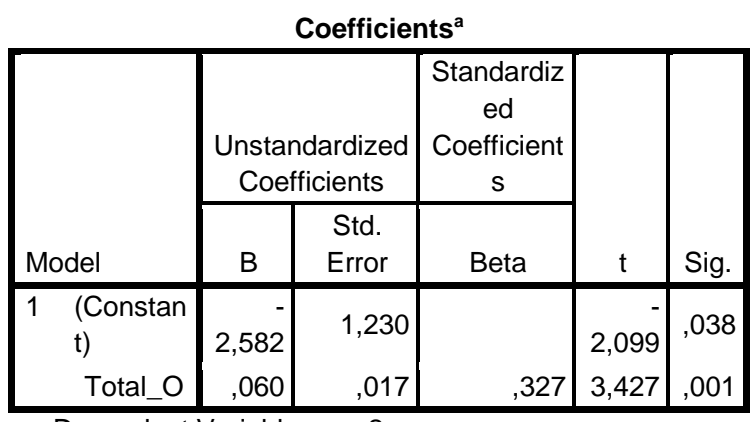

\section{Taksi Online}

\begin{tabular}{|l|c|c|r|r|r|}
\hline Model & $\mathrm{R}$ & $\begin{array}{c}\mathrm{R} \\
\text { Squar } \\
\mathrm{e}\end{array}$ & $\begin{array}{c}\text { Adjusted } \\
\mathrm{R} \\
\text { Square }\end{array}$ & $\begin{array}{c}\text { Std. Error } \\
\text { of the } \\
\text { Estimate }\end{array}$ & $\begin{array}{c}\text { Durbin } \\
\text { Watson }\end{array}$ \\
\hline 1 &, $815^{\mathrm{a}}$ &, 664 &, 661 & 2,170 & 2,224 \\
\hline
\end{tabular}

a. Predictors: (Constant), Total_O

b. Dependent Variable: Total_Y

\section{e. Uji Korelasi}

Taksi Konvensional

Correlations

\begin{tabular}{|c|c|c|c|c|c|c|c|c|c|c|c|}
\hline & & k1 & $\mathrm{k} 2$ & k3 & $\mathrm{k} 4$ & k5 & k6 & k7 & $\mathrm{k} 8$ & k9 & Total_k \\
\hline \multirow[t]{3}{*}{$\mathrm{k} 1$} & Pearson Correlation & 1 & $905^{\prime \prime}$ &, $754^{\mathrm{xn}}$ & $759^{n x}$ & $901^{1 *}$ &, $765^{\pi n}$ & $867^{\pi x}$ & $875^{\mathrm{nx}}$ & $824^{\pi n}$ & $944^{x+2}$ \\
\hline & Sig. (2-tailed) & &, 000 &, 000 &, 000 &, 000 &, 000 &, 000 & .000 &, 000 &, 000 \\
\hline & $\mathrm{N}$ & 100 & 100 & 100 & 100 & 100 & 100 & 100 & 100 & 100 & 100 \\
\hline \multirow[t]{3}{*}{ k2 } & Pearson Correlation &, $905^{\pi \times}$ & 1 & $.697^{\times \pi}$ & $.798^{\pi x}$ & $865^{n \pi}$ &, $771^{x}$ & $820^{2 \pi}$ &, $828^{\text {nn }}$ & $802^{\pi \times}$ & $.924^{* \pi}$ \\
\hline & Sig. (2-tailed) & .000 & & .000 &, 000 & .000 &, 000 & .000 &, 000 &, 000 &, 000 \\
\hline & $\mathrm{N}$ & 100 & 100 & 100 & 100 & 100 & 100 & 100 & 100 & 100 & 100 \\
\hline \multirow[t]{3}{*}{ k3 } & Pearson Correlation & $754^{n *}$ & $697^{\mathrm{x}}$ & 1 &, $722^{x \times}$ &, $739^{x x}$ & $693^{k \pi}$ & $.699^{x \pi}$ &, $704^{\pi \times}$ &, $719^{x \pi}$ & $829^{k x}$ \\
\hline & Sig. (2-tailed) &, 000 &, 000 & &, 000 &, 000 &, 000 &, 000 &, 000 &, 000 &, 000 \\
\hline & $\mathrm{N}$ & 100 & 100 & 100 & 100 & 100 & 100 & 100 & 100 & 100 & 100 \\
\hline \multirow[t]{3}{*}{ k4 } & Pearson Correlation & $759^{\pi *}$ &, $798^{n n}$ &, $722^{\mathrm{Nx}}$ & 1 &, $794^{\mathrm{n}}$ & $802^{n \pi}$ & $.732^{x \pi}$ &, $741^{\mathrm{N}}$ &, $765^{n \pi}$ & $877^{* 1}$ \\
\hline & Sig. (2-tailed) & .000 & .000 & .000 & & .000 & .000 & .000 & .000 & .000 & .000 \\
\hline & $\mathrm{N}$ & 100 & 100 & 100 & 100 & 100 & 100 & 100 & 100 & 100 & 100 \\
\hline \multirow[t]{3}{*}{ k5 } & Pearson Correlation & $901^{* *}$ & $865^{* \pi}$ & $.739^{\text {nx }}$ &, $794^{\mathrm{xx}}$ & 1 &, $799^{n \pi}$ & $854^{\mathrm{nx}}$ &, $852^{\mathrm{xn}}$ & $.792^{\pi *}$ & $938^{k \prime}$ \\
\hline & Sig. (2-tailed) & .000 &, 000 &, 000 &, 000 & &, 000 &, 000 &, 000 &, 000 &, 000 \\
\hline & $\mathrm{N}$ & 100 & 100 & 100 & 100 & 100 & 100 & 100 & 100 & 100 & 100 \\
\hline \multirow[t]{3}{*}{ k6 } & Pearson Correlation & $.765^{\pi x}$ & $.771^{\kappa x}$ & $693^{\text {x }}$ & $802^{x \pi}$ &, $799^{* n}$ & 1 & $800^{2 \pi}$ & $.729^{\mathrm{kn}}$ &, $701^{\times x}$ & $870^{\mathrm{x}}$ \\
\hline & Sig. (2-tailed) & .000 &, 000 &, 000 &, 000 &, 000 & &, 000 &, 000 &, 000 &, 000 \\
\hline & $\mathrm{N}$ & 100 & 100 & 100 & 100 & 100 & 100 & 100 & 100 & 100 & 100 \\
\hline \multirow[t]{3}{*}{ k7 } & Pearson Correlation & $867^{\pi *}$ & $820^{\prime \prime}$ & $699^{x \pi}$ &, $732^{n \pi}$ & $854^{\pi n}$ & $800^{\pi n}$ & 1 & $864^{\pi *}$ & $818^{* \pi}$ & $920^{\prime \prime \prime}$ \\
\hline & Sig. (2-tailed) &, 000 & .000 &, 000 &, 000 &, 000 &, 000 & &, 000 &, 000 &, 000 \\
\hline & $N$ & 100 & 100 & 100 & 100 & 100 & 100 & 100 & 100 & 100 & 100 \\
\hline \multirow[t]{3}{*}{ k8 } & Pearson Correlation & $875^{\pi x}$ & $828^{\prime \prime}$ &, $704^{\mathrm{x}}$ &, $741^{\pi \pi}$ & $852^{\mathrm{xn}}$ & $729^{\prime \prime}$ & $864^{n \pi}$ & 1 & $821^{x \pi}$ & $914^{* x}$ \\
\hline & Sig. (2-tailed) &, 000 & .000 & .000 &, 000 &, 000 & .000 & .000 & & .000 & .000 \\
\hline & $\mathrm{N}$ & 100 & 100 & 100 & 100 & 100 & 100 & 100 & 100 & 100 & 100 \\
\hline \multirow[t]{3}{*}{ k9 } & Pearson Correlation & $824^{x *}$ & $802^{x \pi}$ & $.719^{x x}$ &, $765^{x \pi}$ & $.792^{* \pi}$ &, $701^{n \pi}$ & $.818^{* \pi}$ & $821^{n}$ & 1 & $892^{\text {nx }}$ \\
\hline & Sig. (2-tailed) &, 000 &, 000 &, 000 & .000 &, 000 &, 000 & .000 & .000 & &, 000 \\
\hline & $N$ & 100 & 100 & 100 & 100 & 100 & 100 & 100 & 100 & 100 & 100 \\
\hline \multirow[t]{3}{*}{ Total_k } & Pearson Correlation & $944^{\pi n}$ & $924^{* \pi}$ & $829^{\pi \pi}$ & $877^{x \pi}$ & $938^{* n}$ & $870^{\pi x}$ & $920^{x \pi}$ &, $914^{\text {nN }}$ & $892^{n \pi}$ & 1 \\
\hline & Sig. (2-tailed) & .000 & .000 & .000 & .000 & .000 & .000 & .000 & .000 & .000 & \\
\hline & $\mathrm{N}$ & 100 & 100 & 100 & 100 & 100 & 100 & 100 & 100 & 100 & 100 \\
\hline
\end{tabular}


Vol. 5 No.1`Maret 2020

Correlations

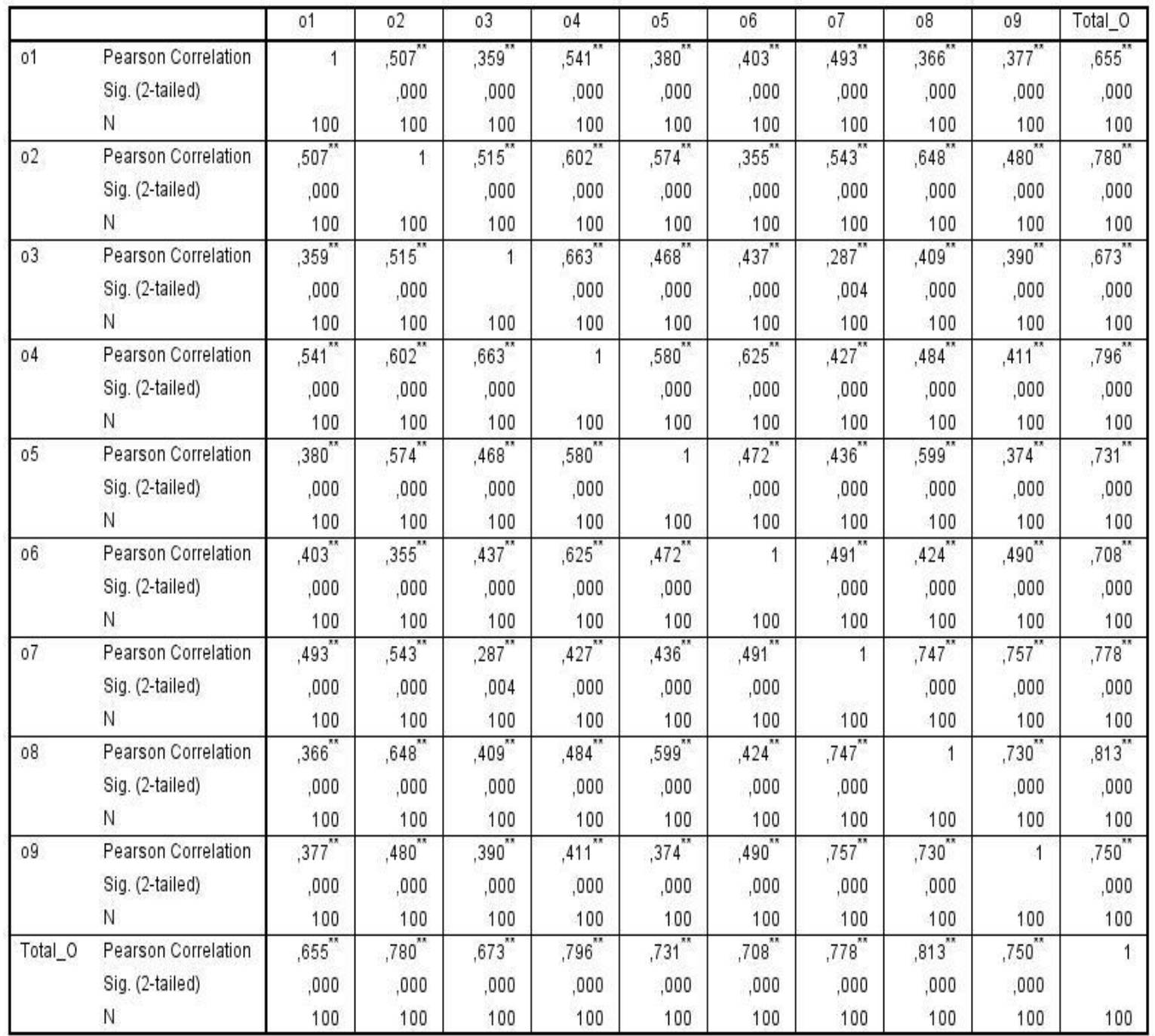

**. Correlation is significant at the 0.01 level (2-tailed).

f. Uji Koefisien Determinasi $\left(R^{2}\right)$

\section{Taksi Konvensional}

Model Summary

\begin{tabular}{|c|c|c|r|r|r|}
\hline Model & $\mathrm{R}$ & $\begin{array}{c}\mathrm{R} \\
\text { Squar } \\
\mathrm{e}\end{array}$ & $\begin{array}{c}\text { Adjusted } \\
\mathrm{R} \\
\text { Square }\end{array}$ & $\begin{array}{c}\text { Std. Error } \\
\text { of the } \\
\text { Estimate }\end{array}$ & $\begin{array}{c}\text { Durbin } \\
\text { Watson }\end{array}$ \\
\hline 1 &, $932^{\mathrm{a}}$ &, 868 &, 867 & 2,123 & 2,003 \\
\hline
\end{tabular}

a. Predictors: (Constant), Total k

b. Dependent Variable: Total_Y
Taksi Online

\begin{tabular}{|l|c|c|r|r|r|}
\multicolumn{7}{|c|}{ Model Summary $^{\text {b }}$} \\
Model & $\mathrm{R}$ & $\begin{array}{c}\mathrm{R} \\
\text { Squar } \\
\mathrm{e}\end{array}$ & $\begin{array}{c}\text { Adjusted } \\
\mathrm{R} \\
\text { Square }\end{array}$ & $\begin{array}{c}\text { Std. Error } \\
\text { of the } \\
\text { Estimate }\end{array}$ & $\begin{array}{c}\text { Durbin } \\
\text { Watson }\end{array}$ \\
\hline 1 &, $815^{\mathrm{a}}$ &, 664 &, 661 & 2,170 & 2,224 \\
\hline
\end{tabular}

a. Predictors: (Constant), Total_O

b. Dependent Variable: Total_Y 
g. Uji F

Taksi Konvensional

ANOVA $^{\mathrm{a}}$

\begin{tabular}{|c|c|c|c|c|c|}
\hline Model & $\begin{array}{l}\text { Sum of } \\
\text { Squares }\end{array}$ & $d f$ & $\begin{array}{l}\text { Mean } \\
\text { Square }\end{array}$ & $\mathrm{F}$ & Sig. \\
\hline $\begin{array}{ll}1 & \text { Regressio } \\
n\end{array}$ & $\begin{array}{r}3333,39 \\
2\end{array}$ & 1 & 3333,392 & $\begin{array}{l}739,59 \\
1\end{array}$ &, 000 \\
\hline Residual & 504,793 & 112 & 4,507 & & \\
\hline Total & $\begin{array}{r}3838,18 \\
4\end{array}$ & 113 & & & \\
\hline
\end{tabular}

a. Dependent Variable: Total_Y

b. Predictors: (Constant), Total_k

h. Uji t

Taksi Konvensional

Coefficients $^{a}$

\begin{tabular}{|c|c|c|c|c|c|}
\hline \multirow[b]{2}{*}{ Model } & \multicolumn{2}{|c|}{$\begin{array}{c}\begin{array}{c}\text { Unstandardiz } \\
\text { ed } \\
\text { Coefficients }\end{array} \\
\end{array}$} & $\begin{array}{c}\text { Standardize } \\
\mathrm{d} \\
\text { Coefficients } \\
\end{array}$ & \multirow[b]{2}{*}{$t$} & \multirow[b]{2}{*}{ Sig. } \\
\hline & B & \begin{tabular}{|l} 
Std. \\
Error
\end{tabular} & Beta & & \\
\hline $\begin{array}{cl}1 & \text { (Constant } \\
& \text { ) }\end{array}$ & $\begin{array}{l}2,29 \\
7\end{array}$ & 1,018 & & 2,256 &, 026 \\
\hline Total_k & $\begin{array}{l}, 42 \\
0\end{array}$ & ,015, & ,932 & $\begin{array}{l}27,19 \\
5\end{array}$ &, 000 \\
\hline
\end{tabular}

a. Dependent Variable: Total_Y
Taksi Online

\begin{tabular}{|c|c|c|c|c|c|}
\hline \multicolumn{6}{|c|}{ ANOVA $^{a}$} \\
\hline Model & $\begin{array}{l}\text { Sum of } \\
\text { Squares }\end{array}$ & df & $\begin{array}{c}\text { Mean } \\
\text { Square }\end{array}$ & $\mathrm{F}$ & Sig. \\
\hline $\begin{array}{ll}1 & \text { Regressio } \\
n\end{array}$ & 912,186 & 1 & 912,186 & $\begin{array}{l}193,69 \\
4\end{array}$ & 000 \\
\hline Residual & 461,524 & 98 & 4,709 & & \\
\hline Total & $\begin{array}{r}1373,71 \\
0\end{array}$ & 99 & & & \\
\hline
\end{tabular}

a. Dependent Variable: Total_Y

b. Predictors: (Constant), Total_O

Taksi Online

Coefficients $^{\mathrm{a}}$

\begin{tabular}{|c|c|c|c|c|c|}
\hline \multirow[b]{2}{*}{ Model } & \multicolumn{2}{|c|}{$\begin{array}{c}\text { Unstandardiz } \\
\text { ed } \\
\text { Coefficients }\end{array}$} & $\begin{array}{c}\text { Standardiz } \\
\text { ed } \\
\text { Coefficients }\end{array}$ & \multirow[b]{2}{*}{ t } & \multirow[b]{2}{*}{ Sig. } \\
\hline & B & Std.Erro & Beta & & \\
\hline $\begin{array}{ll}1 & \text { (Constant } \\
& \text { ) }\end{array}$ & $\begin{array}{l}4,10 \\
2\end{array}$ & 1,964 & & \begin{tabular}{|l|}
2,08 \\
9
\end{tabular} & $\begin{array}{r}, 03 \\
9\end{array}$ \\
\hline Total_O & $\begin{array}{r}, 38 \\
7\end{array}$ & ,028 & 815, & $\begin{array}{l}13,91 \\
7\end{array}$ & $\begin{array}{r}00 \\
0\end{array}$ \\
\hline
\end{tabular}

a. Dependent Variable: Total_Y

\section{E. Kesimpulan dan Saran-saran}

\section{Kesimpulan}

Berdasarkan hasil analisis dan pembahasan yang telah dilakukan oleh penulis, maka dapat disimpulkan bahwa secara keseluruhan dan dirata-ratakan responden setuju yang mencakup variabel Keputusan Menteri Perhubungan Nomor 26 Tahun 2017 Pasal 5 Tentang Pelayanan Angkutan Orang dengan Menggunakan Taksi, dan variabel Keputusan Memakai Taksi.

\section{Saran-saran}

Berdasarkan kesimpulan tersebut, maka saran yang dapat penulis berikan kepada Go-Car dan Grab Car, pada khususnya dapat lebih memperhatikan Keputusan Menteri Perhubungan Nomor 26 Tahun 2017 Pasal 5 Tentang Pelayanan Angkutan Orang dengan Menggunakan Taksi untuk menangkap sinyal perluasan akses teknologi.

\section{F. DAFTAR PUSTAKA}

Aturan Tarif Taksi Baru Untungkan Grab \& Gojek? 19 June 2019. Tech-Taufan Adharsyah, CNBC Indonesia. Jakarta. 
Data Konsolidasi Berkala Kementerian Dalam Negeri Semester 1 Tahun 2019, Dinas Kependudukan dan Pencatatan Sipil Kota Pontianak.

Hasan, M. Iqbal. (2002). Pokok-pokok Materi Statistik 1 (Statistik Deskriptif), edisi kedua. Jakarta: PT Bumi Akrasa.

Keputusan Menteri Perhubungan Nomor 26 Tahun 2017 Pasal 5 Tentang Pelayanan Angkutan Orang dengan Menggunakan Taksi.

Laporan Penelitian Dilema Sosial Ojek Online Gojek(1).pdf, 2019.

Majalah Info Singkat Ekonomi dan Kebijakan Publik. Kajian Singkat Terhadap Isu Aktual dan Strategis. Vol. IX, No. 06/II/Puslit/Maret/2017.

Miro, F. (2004). Perencanaan Transportasi untuk Mahasiswa, Perencana dan Praktisi. Erlangga. Jakarta.

Nasution, M. Nur. (1996). Manajemen Transportasi, Ghalia Indonesia, Jakarta.

Pontianak (Antara News)-Minggu, 25 Februari 2018.

Rangkuti, Freddy. (1997). Riset Pemasaran, edisi pertama. Jakarta: Gramedia Pustaka Utama.

Rifusa, Agus Imam. (2010). Analisis Faktor-faktor Permintaan Transportasi Busway.

Salim, Abbas. (2013). Manajemen Transportasi. edisi 1 Cet. 10. Depok: RajaGrafindo Persada (Rajawali Pers).

Sani, Zulfikar. (2012). Trasnportasi Suatu Pengantar, Universitas Indonesia, Jakarta.

Sudjarwo. (2001). Metodologi Penelitian Sosial. Bandung: Mandar Maju. 